\title{
The Structure of Podocarpus spinulosus, (Smith) R. Br.
}

\author{
BY \\ F. T. BROOKS, M.A. \\ Senior Demonstrator of Botany, Cambridge University.
}

AND

WALTER STILES, B.A.

Assistant-Lecturer in Botany in the University of Leeds.

With Plate XXI.

INTRODUCTION.

THE following account of the structure of Podocarpus is based mainly 1 upon material of Podocarpus spinulosus, (Smith) R. Br., which was obtained from the Botanic Gardens, Sydney, New South Wales. The material was sent to Professor Seward by Mr. Maiden, and was handed over to us for investigation.

Material of Podocarpus alpinus obtained from the Royal Gardens, Kew, and of one or two other species of which only a limited stock was available, were examined at the same time for the sake of comparison.

Pilger (13) in his monograph of the Taxaceae places Podocarpus and four other genera-Pherosphaera, Microcachrys, Saxegothaea, Dacrydiumin the sub-family Podocarpoideae, the other sub-families of the group being the Phyllocladoideae, containing the single genus Phyllocladus, and the Taxoideae, comprising Taxus, Torreya, Cephalotaxus. Pilger evidently then considers the Podocarpoideae to be very closely related to the Taxoideae. Later work, however, would appear to necessitate a modification of this view.

The systematic position of Podocarpus and closely allied genera is discussed in the latter part of this paper.

The genus Podocarpus, as described in Pilger's monograph, contains no less than sixty-three species, the large majority of which are found in the Southern Hemisphere. New Zealand, Australia, and the Malayan islands are at present the home par excellence of the genus, while smaller centres of distribution are such different regions as East Africa (São Thomé), Cape Colony and Natal, Assam, Japan, China, Central America, West Indies, and Chili. Where the genus is present within the tropics it is generally

[Annals of Botany, Vol. XXIV. No. XCIV. April, 19ro.] 
found on mountain ranges at a considerable elevation. Just as Pinus may be considered the dominant Coniferous genus of the Northern Hemisphere, so Podocarpus occupies a similar position among the Conifers of the Southern regions.

In regard to the distribution of the genus in geological times, most of the specimens referred to Podocarpus or closely allied genera have been determined from leaves only, and it is well known that leaf determinations are frequently untrustworthy. In this connexion mention may be made of the striking similarity in external features between the leaves of some species of Agathis and those of the Nageia section of Podocarpus. Seward and Ford (16) found, on cutting sections of a species originally referred to Dammara Motleyi, that the plant so named is really a species of Podocarpus.

Assuming that some at least of the specimens are correctly determined, then Podocarpus, like Araucaria, must have been widely distributed in the North temperate zone during the later Mesozoic and Tertiary times. Pilger states that the leaves from the Potomac or later Mesozoic flora of the United States are to be referred to the Nageia section of the genus on account of the plurinerved form of venation, while leaves from the Eocene and Miocene strata of Europe belong to the uninerved sections of the genus.

Podocarpus shows a considerable range of habit among its many species. Several of them are large trees; e.g. P. amarus attains a height of sixty metres in Java, and P. dacrydioides forms practically pure forests in New Zealand. On the other hand, $P$. alpinus, found on mountains in Tasmania, is a low shrub, and $P$. nivalis, on exposed places in the alpine regions of New Zealand, becomes a dwarf shrub with prostrate branches.

\section{Vegetative Organs.}

\section{Stem.}

The structure of the wood of $P$. spinulosus is very similar to that of $P$. macrophyllus described by Penhallow. Resin canals are absent in the wood, but there is a ring of them present outside the phloem. Their place in the wood is taken by resin cells, which are present in considerable numbers. The bordered pits of the secondary tracheides are uniseriate; no trace of the Araucarian type of pitting could be discerned, such as has been described by Gothan (8) for Dacrydium spp. and for Saxegothaea by Beust (3), Gothan (8), and Stiles (17). The medullary rays are invariably uniseriate, and are from one to three cells deep. The cells of the rays contiguous to the pith frequently contain resinous material, but apart from this all the cells of the rays are alike, there being no tracheidal cells such as are met with in the rays of Pinus and some other Conifers. There is a small central pith which consists mainly of resin cells and groups of stone cells; the latter are very conspicuous. Resin cells are also extremely abundant in the cortex. 


\section{Leaf.}

The leaves of $P$. spinulosus, as indeed is the case in the large majority of the species, are arranged spirally on the stem axis. It is interesting to note, however, that in the Nageia section of the genus the leaves have a decussate or subdecussate arrangement. The leaf of $P$. spinulosus is about $4-6 \mathrm{~cm}$. long by 3-4 $\mathrm{mm}$. broad, and ends in an acute point.

The anatomy of the leaf of $P$. spimulosus is very similar to that of $P$. chilinus described by Worsdell (29), and that of $P$. neriifolius and $P$. falcatus examined by Bernard (1). As in all the narrow-leaved species of the genus, there is a single vascular bundle; this is accompanied on its phloem side by a resin canal. Placed laterally to the vascular bundle is the transfusion tissue, which is extremely well developed. The transfusion tracheides show numerous reticulations on their walls when the leaf is cut at right angles to the midrib.

On the side of the transfusion tissue remote from the bundle, there is a layer of parenchymatous cells, beyond which is the 'accessory transfusion tissue', such as is described by Worsdell for P. chilinus. This tissue runs outwards almost to the margin of the leaf. This 'accessory transfusion tissue' of Worsdell corresponds to the 'hydrostéréome transversal' of Bernard. The cells composing this tissue are long and lignified, and, as Worsdell points out, they have the appearance of stone cells rather than of tracheides. Their function presumably is primarily that of strengthening the lamina of the leaf.

\section{REPRODUCTIVE ORGaNS.}

With regard to the reproductive organs Podocarpus is generally dioecious, though very rarely monoecious. This distribution of the sexes is the same as that in Dacrydium and in Microcachrys, but Saxegothaea is monoecious. The reproductive organs in Taxus are also dioecious, and in Araucaria and Agathis they are generally dioecious.

\section{(I) Male Cone.}

The male cones are borne either singly on a very short axis which arises in the axil of an ordinary foliage leaf, or more often they are arranged in clusters of two to four which are borne on a similar abbreviated axis, each cone being attached by means of a short stalk. The male cone is from $I \mathrm{~cm}$. to $\mathrm{I} .5 \mathrm{~cm}$. long and about $2.5 \mathrm{~mm}$. in diameter. At the base of each male cone are a few tiny bracts which are spirally arranged along the short stalk of the cone. The axis of the cone bears a number of spirally arranged sporophylls, each one of which consists of a pedicel which becomes flattened distally to a lamina on either side. Each sporophyll bears on its under surface two ovoid microsporangia. 
The axis of the cone, as seen in transverse section, contains a ring of collateral vascular bundles of the usual structure. No trace of centripetal xylem could be found, such as is present in the axis of the male cone of Saxegothaea (17). Each vascular bundle is accompanied by a single resin canal outside the phloem, but it seems to be the general rule that these resin canals are not functional, for in most of them no distinct epithelial layer could be seen. On the other hand, resin cells are frequent throughout the fundamental tissue. A single vascular bundle, consisting of a few tracheides and phloem elements, passes out to each sporophyll. It arises by division of one of the axial bundles, the plane of division being radial; the two derived bundles lie side by side before one of them passes out to the sporophyll. The tracheides in the sporophyll are somewhat scattered, and some of them may represent centripetal xylem. The phloem dies out before the xylem, as it ordinarily does in the termination of the vascular bundles of the leaves. A small resin canal, which appears to be nonfunctional, accompanies the single vascular bundle in its passage from the cone axis, but this canal dies out very quickly. In Saxegothaea, on the other hand, the resin canal of the sporophyll is a much more conspicuous structure, and passes out practically as far as the xylem elements extend.

The microsporangia of our material were either ready for dehiscence or else dehiscence had already taken place. Remains of two layers of cells within the sporangium wall could be made out. The wall of the sporangium is very much like that of Saxegothaea $(10,17)$ and Araucaria (16). It is one cell wide except on the outside, and the vertical cell-walls are very thick, and have numerous strengthening bands on them running at right angles to the surface (cf. Pl. XXI, Fig. I). The line of dehiscence of the sporangium is oblique, as can be seen by an examination of P1. XXI, Fig. 2. Pilger (13) states that the dehiscence of the sporangium in the Taxaceae is longitudinal, but this is without doubt incorrect for $P$. spinulosus. Thibout (20) correctly figures the dehiscence of the microsporangia of several species of Podocarpus as being oblique. In Saxegothaea (17) the line of dehiscence is transverse.

\section{(2) Pollen-grains.}

As is well known, the pollen-grains of Podocarpus are winged like those of Pinus. The material of P. spinulosus available contained only pollen-grains which were mature. The material had been fixed in a dilute solution of formalin, and apparently had all been collected at one time. Several observers have recently related the occurrence of as many as eight prothallial cells in the pollen-grains of different species of Podocarpus. Thibout (20) describes the presence of several prothallial cells in $P$. polystachyus. Coker (5) mentions the division in P.coriacea of the two original prothallial cells, but he considers that these divisions are abnormal. 
Jeffrey and Chrysler (9) found that in two other species, $P$. ferrugineus and $P$.dacrydioides, there were as many as eight prothallial cells present, and that the generative cell also had divided. They and Miss Young (31) also record several prothallial cells in species of Dacrydium. Jeffrey and Chrysler incline to the view that these divisions of the prothallial cells and the generative cell cannot be regarded as a primitive feature. Burlingame (4) reports the occurrence of a similar group of prothallial cells in $P$. totarra Hallii. Norén (10) records a similar complex of prothallial cells in Saxegothaea, and Thomson (23) describes the occurrence of the same in Microcachrys. The latter (21) has also found that in Agathis as many as thirty to forty prothallial cells may be present.

It was thought advisable to compare the structure of the male gametophyte of $P$. spinulosus with that of other species of Podocarpus previously described. Microtome sections of male cones were cut whose microsporangia had not dehisced, and were stained with Heidenhain's Iron Alum Haematoxylin with a background stain of Orange G. It will be seen on examination of Pl. XXI, Figs. $3^{-8}$, that the contents of the pollengrains are almost exactly the same as those figured by Jeffrey and Chrysler for $P$. ferrugineus and $P$. dacrydioides. In Figs. 3 and 4 both prothallial cells have divided in a plane at right angles to that of the section, but in Figs. 5 and 6 divisions in the first and second prothallial cells respectively have not occurred in this plane. From an examination of Fig. 7 , which is a section of a pollen-grain cut tangentially at its prothallial end, it is apparent that there may be another plane of division of the prothallial cells at right angles to that indicated in Figs. 3 and 4 , \&c. Thus as many as eight prothallial cells may be present. The generative cell is generally conspicuous with its aggregation of protoplasm around the central nucleus. It is evident from Fig. 5 that the generative cell sometimes divides before the liberation of the pollen in a manner which is probably the same as that described for the first time by Jeffrey and Chrysler (9) as occurring in the pollen of $P$. ferrugineus and $P$. dacrydioides. The tubenucleus is the largest nucleus present in the pollen-grain. All the nuclei of our material were in the resting condition, as indicated by the large nucleolus and absence of a reticulum. After a time the walls of the prothallial cells break down, and the nuclei come to lie free in the cytoplasm, as will be seen on examination of Fig. 8. Jeffrey and Chrysler record a similar phenomenon in $P$. polystachyus.

It is apparent then from this examination of $P$. spinulosiss, and from the résumé of work done on other species given above, that the multicellular condition of the male gametophyte of Podocarpus must be considered a characteristic of the genus, especially as the species investigated come from widely different regions (New Zealand, Australia, Cuba, Java).

The fact that a similar condition of the male gametophyte exists in 
Dacrydium, Microcachrys, and Saxegothaea is another indication that the Podocarpeae are a natural group.

It is impossible, with our present meagre knowledge of the inter-relationships of the Conifers, to say whether this multicellular condition of the male gametophyte of Podocarpus is primitive or derived. Jeffrey and Chrysler (9) consider that it is not a primitive feature, but it seems to us that data for deciding the question are not at present available. The fact that a similar prothallial complex is present in Saxegothaea and Microcachrys-two genera which on other grounds are considered to be relatively primitiveis a point in favour of considering the prothallial complex of Podocarpus primitive. The fact that the divisions of the nuclei of the prothallial cells are karyokinetic is in keeping with the interpretation that the occurrence of several such cells is a normal feature for the genus. The presence of wings in the pollen-grains of Podocarpus does not point to any necessary relationship with the Abietineae, a group from which we consider the Podocarpeae to be considerably removed, for in the Podocarpeae the wings on the pollen-grains appear to have been evolved within the group. ${ }^{1}$ Jeffrey and Chrysler (9) consider, on the other hand, that the ground plan of the male gametophyte of Podocarpus is very similar to that of the Abietineae, but we cannot gather from their statements what adequate grounds they have for this conclusion. Jeffrey and Chrysler bring the proliferation of the prothallial cells in Araucarieae into line with the peculiar protosiphonogamic method of fertilization in this group described by Thomson (22). But this does not account for the occurrence of several prothallial cells in Podocarpus. ${ }^{2}$ On examining our material it was seen that the pollen-grains alight in the micropyle, and so presumably the growth of the pollen-tubes is a normal one through the nucellus.

\section{(3) Female Fructification.}

Of the female fructification we had material of three species, Podocarpus spimulosus, $P$. alpinus, and a third species. We had the first in largest quantity, so this species will be described more fully and the others compared with it.

The female fructification is borne laterally on the stem in the axil of a bract about six millimetres long, resembling a small foliage leaf. In the axil of the bract is the peduncle, about six or seven millimetres long and nearly a millimetre wide, and somewhat flattened in the vertical plane at right angles to that containing the main axis and the peduncle. At its upper end it bears three pairs of bracts decussately arranged (cf. Pl. XXI, Fig. 9). The lowest pair are small, about one and a half millimetres long, and are recurved and more or less leaf-like. They lie in the plane containing both stem and pedicel. The other two pairs of bracts 
which are inserted close together, appear more or less swollen and fleshy; they are about five or six millimetres long, and fused together except at the tip. The two lower bracts are about a millimetre longer than the upper pair; each bears, just above the point where the four bracts become free from one another, a single stalked anatropous ovule. Occasionally one of the two lower bracts is sterile, while the upper pair of bracts in all cases examined were both sterile. Generally one of these is developed more strongly than the other. Pilger (13) notes a good deal of variation in the bracts of $P$. spinulosus. Sometimes the lowest pair may be missing, while the other four may vary a great deal in size relatively to one another. The following account of the internal structure is of the normal case where the two lowest bracts are present, and the next two bracts are fertile and of approximately equal size, while the uppermost pair are also fairly well developed.

The peduncle contains in transverse section a somewhat elliptical ring of endarch collateral bundles which anastomose somewhat. Each bundle is accompanied on its phloem side by a single resin canal.

A section through the base of the fused bracts shows a similar structure (Pl. XXI, Fig. IO). The bundles divide occasionally and reunite, the resin canals sometimes dividing as well as the bundle; in other cases the canal arises de novo outside one of the bundles, and occasionally it may be absent altogether from one of the bundles. This behaviour points to the canals being functionless, and there is no epithelium properly developed. Resin cells are extremely abundant throughout the whole of the parenchyma of the bracts.

At a higher level the ring of bundles widens out in one plane, and the bundles then come to arrange themselves in two groups of three at opposite sides of the wider diameter with two bundles between them (Pl. XXI, Figs. II and 12).

The two groups at each end belong to the fertile scales and ovules, the bundles between them belonging one to each of the sterile scales. This state of affairs is intermediate between that figured by Van Tieghem (27) for Podocarpus sinensis, where the sterile bracts also contain each a group of three bundles, and that figured by Strasburger (18) for Podocarpus chinensis, Wall., apparently the same species as that described by Van Tieghem, where the sterile bracts have no vascular supply. In one place the stronger of two sterile bract bundles had two small groups of xylem elements some little distance away from it on the xylem side (Pl. XXI, Figs. I2 and 19); these apparently correspond to the two inner bundles of one of the groups in Van Tieghem's figures. As the bundles of the sterile bracts die out, some transfusion tracheides appear.

Of the group of three bundles serving the fertile scale, the middle one, passes out into the bract subtending the ovule, the other two approach 
one another and fuse by their margins to form a V-shaped bundle with its xylem and phloem inversely orientated with regard to the xylem and phloem of the subtending bract bundle (Pl. XXI, Fig. I3). This V-shaped bundle next straightens itself out (Pl. XXI, Fig. I4) and begins to divide into three (PI'. XXI, Fig. I5), so that as the chalazal end of the ovule is approached there are found three bundles, each, as a rule, with a small non-functional resin canal (Pl. XXI, Fig. I6).

At the chalazal end of the ovule the tivo lateral bundles bend round through about a right angle and descend, one on each side of the ovule, for a short distance towards the micropyle; as seen in transverse section they lie on the diameter of the ovule (Pl. XXI, Fig. I7). The central bundle continues its course over the top of the ovule, and in so doing divides into two bundles (P1. XXI, Fig. I8) which descend a short distance towards the micropyle (Pl. XXI, Fig. I7). All these descending bundles soon die out, and all show a tendency to amphivasal structure (Pl. XXI, Fig. 20).

The nucellus of the ovule is surrounded by two integuments. The inner is fused for about half its length with the nucellus. The outer integument or epimatium is free from the inner for a short distance at the micropyle end, and on the side remote from the ovular stalk; on the other side it is either not present or is completely fused with the stalk. ${ }^{1}$

Where free, the innermost layer of the inner integument often consists largely of resin cells. These are apparently continued into the part of the ovule where the inner integument and nucellus become fused, and so apparently mark the line of division between these. A zone containing larger and more numerous resin cells also seems to mark the line of division between the inner and outer integuments, but these do not extend far enough towards the chalaza, and are not definite enough to enable one to state whether the descending bundles belong to any particular integument or to the nucellus.

In a species of Podocarpus grown in the Cambridge Botanic Garden, the structure was found, on the whole, to be similar. The peduncle is borne in the axil of an ordinary foliage leaf. In the stage examined the peduncle is about six millimetres long and nearly a millimetre broad, and, as in $P$. spinulosus, is flattened in a vertical plane at right angles to that containing the peduncle and the branch bearing it. In the few specimens available for examination the lowest pair of leaf-like bracts were not present, and the whole fructification consisted of two pairs of bracts fused together, of which one or both of the lower pair bore ovules. The arrangement of the bundles is practically the same as in $P$. spinulosus. One bundle of the stem passes into the subtending leaf, while the two bundles on each side of it pass into the peduncle. These almost immediately divide up into a ring of bundles. At the base of the fused bracts 
two sets of three bundles are present; these belong to the fertile scales. One of these bundles on each side divides, and so gives rise to the bundles of the two sterile scales. Additional small bundles may be present on the inside of the sterile scale bundles as in $P$. spinulosus. The xylem of the bundles tends to be semicircular in shape, more or less enclosing the phloem on three sides. The resin canals, of which there is one on the phloem side of each bundle, are much larger than in $P$. spinulosus, and as a rule the resin duct divides after the division of the bundle to which it belongs. The ovular bundle, as in $P$. spinulosus, divides into three; when on a level with the nucellus, transfusion tissue begins to appear both centripetally and laterally, and the division into three bundles is no longer obvious. These bundles die out at the chalaza, and do not descend on the sides of the ovule as in P. spimulosus. For the last part of their course they are composed of transfusion-like tracheides only.

In Podocarpus alpinus, material of which was obtained from the Royal Gardens, Kew, the peduncle is very short, being less than a millimetre long. The lowest pair of bracts are extremely small and scalelike, although Pilger (13) states they are absent altogether; of the next pair only one bears an ovule, while of the upper sterile pair one is often aborted altogether, and the other is small compared with those of the lower pair.

The vascular system at the base of the fused bracts consists of four bundles arranged along the sides of a square; of these one serves the fertile scale and two the ovule it subtends, the fourth serving the opposite sterile scale. The upper sterile scale has usually no vascular supply.

The two ovular bundles fuse as in the other species described, but at first almost the whole of the xylems of the two bundles come in contact, so that the resulting bundle is almost concentric; further up, however, it straightens itself out. Nearer the chalaza it divides into two bundles which curve over the top of the ovule and descend a little way towards the micropyle on the sides of the ovule in much the same way as the lateral bundles do in $P$. spinulosus. In $P$. alpimus the resin canal accompanying each of these two bundles extends down to the level of the nucellus where it occurs on the inner margin of the outer integument, to which these bundles would appear to belong. Other canals also appear on the inner margin of the outer integument; these presumably correspond with the middle bundle of $P$. spinulosus, which bends over the ovule and then divides into two. On the whole, it would seem from their behaviour in $P$. alpinus that these bundles all belong to the outer integument, but the evidence at present is insufficient to decide this point.

As far as the female fructification is concerned, the Podocarpeae obviously fall into two divisions; one in which the megasporophylls are aggregated into cones, and which comprises the monotypic genera Saxegothaea and Microcachrys, the other in which the fertile megasporophylls 
are mostly either solitary or associated in pairs, and which includes the genera Dacrydium and Podocarpus. A remarkably different condition exists in two species of Podocarpus, $P$. andinus and $P$. spicatus, in which the megasporophylls bearing ovules occur at intervals along the fertile branch.' In all a single ovule is present on the upper surface of the megasporophyll, and is borne in a more or less reversed position.

Assuming that the Podocarpeae form a natural group, a conclusion which from general considerations seems inevitable, there appears to be every reason to suppose that the state found in Dacrydium and Podocarpus is derived from that in Saxegothaea and Microcachrys by reduction in the number of scales in the cone, from an indefinite number to two or three pairs decussately arranged in Podocarpus. Here very. occasionally both scales of two pairs may contain ovular bundles (27); in some species normally both bracts of the lower pair are fertile, while in many species, e.g. P.alpinus and P. elatus, only one scale of the whole fructification is fertile. The female fructification is then to be regarded as a very reduced cone. In $P$. andinus and $P$. spicatus it would appear that the axis, instead of becoming very much shortened, has lengthened out a good deal, and the sporophylls are now separated by comparatively. long internodes. The insertion of the ovule differs markedly from that found in Saxegothaea and Microcachrys. In these genera the single ovule is sessile on the upper surface of the megasporophyll, whereas in Podocarpus it is borne on a stalk which apparently arises from the upper surface of the bract which bears it. Dacrydium exhibits transitions between; the two cases, for in some species the ovule is borne on the upper surface of the scale, in others it is more or less as in Podocarpus. The internal structure of the megasporophylls of the Podocarpeae also shows a similar series of stages. In Saxegothaea one bundle leaves the axis of the cone and gives off the ovular supply by branches arising from it; in Microcachrys the two bundles are presumably separate from the cone axis, but very close together $(30) ;{ }^{1}$ in Podocarpus one bundle of the peduncle passes up into the megasporophyll, while two others, one on each side of the sporophyll, join up and supply the ovule.

It seems fairly clear that Saxegothaea is primitive for the Podocarpeae, and the state of things found in Podocarpus is derived from that found in Saxegothaea. The much smaller amount of centripetal xylem and the loss of function of the resin canals in some species support this view.

The independence of the vascular supply of the ovule from the vascular bundle of the subtending bract can be easily, and it seems to us reasonably, explained as due to basipetal evolution of the vascular system, as the ovule has become more and more important in relation to the subtending bract.

1 But Thomson (24) states that the sporangium bundle arises in the same way as that of Saxegothaea, by branching from the sporophyll bundle. 
In Saxegothaea, where the ovule is a small appendage of the bract, the bundles supplying it arise by branching from the bundle of the sporophyll: As the ovule has become relatively of more importance than the bract, its vascular supply has also become of more importance, until in Podocarpus the vascular supply of the ovule is carried down into the peduncle independently of the supply of the megasporophyll. This point of view has alsa been emphasized by Thomson (24), in regard to the megasporophyll of Dacrydium, in some species of which the behaviour of the bundles is very similar to that of Podocarpus.

With regard to the branching of the ovular bundles, Favre (7) has rather vaguely described their behaviour in Podocarpus sinensis, where he says the ovular bundle divides a little below the summit of the organ into a large number of branches which extend downwards in the plane of separation of the integuments and so form a vascular cupule which is prolonged up to the point where the nucellus becomes free. In $P$. spinulosus and $P$. alpinus the (presumably) integumentary bundles are much less developed, and in Podocarpus sp. they are practically not developed at all.

How the ovular bundles are to be homologized with those found in the ovules of other Gymnosperms (11) there are not at present sufficient data to decide. Favre's species would apparently throw light on this question, but his description is too vague to be of much help. Moreover Strasburger's description of $P$. chinensis (19), which is apparently the same species as $P$. sinensis, is almost identical with our description of $P$. spinulosus:

In $P$. spinulosus and $P$. alpinus there seems to be an outer integumentary system arising from the chalazal bundles. Whether there is an inner integumentary system as well cannot yet be decided, but what facts there are available point against it.

\section{General Considerations.}

The relationships of Podocarpus have already been discussed at some length in the course of this paper. The genus seems to be a recently, modified type with close relationships to Dacrydium, Microcachrys, and Saxegothaea. Its present wide geographical range, the wings on the pollen-grains, the frequently functionless nature of the resin canals, and the peculiar structure of the female fructification are all considerations which point to this conclusion. Microcachrys and Saxegothaea are undoubtedly more primitive than Dacrydium and Podocarpus. Saxegothaea would appear to be a connecting link with the Araucarieae, and the complex of prothallial cells in the pollen-grains of the Podocarpeae generally can be brought into relation to the numerous prothallial cells described for the pollen-grains of the Araucarieae.

Miss Robertson (14) has pointed out that the somewhat isolated genus Phyllocladus has definite points of resemblance to Podocarpus, on the one 
hand, and relationships less marked, on the other, to the Taxeae. It would seem to us that the differences between Phyllocladus and the Taxeae are greater than Miss Robertson supposes-two of her four points of resemblance between them being of an unsatisfactory nature. Thus the markings of the centripetal wood of Phyllocladus are practically the same as those in the transfusion tracheides of Podocarpus, and the presence of a certain amount of centripetal wood in Phyllocladus is not sufficient evidence of phylogenetic relationship.

There are considerable differences in the two groups between the structure of the male cones, and these differences become no less apparent when we consider the male gametophytes. The only point of resemblance between the female fructifications of the two groups is the generally fleshy consistency of the ripe seeds. Phyllocladus is certainly near the Taxeae in its female fructification, because its symmetrical arillus, like that of the latter group, only develops at a late stage. There seem to be no striking resemblances in anatomical characters between the Podocarpeae and the Taxeae.

Thus the points of similarity between the Podocarpeae and the Taxeae do not seem to us to be very striking, though, as has been supposed in the past, the two groups may perhaps be connected by Phyllocladus.

With regard to the relationships of the Podocarpeae with the Abietineae, there appears to be no evidence of any recent phylogenetic connexion between the two groups. The structure of the male gametophytes in the two groups has already been discussed, and the anatomical characters both of the female reproductive structures and of the vegetative organs are very different in these two orders of Coniferae.

\section{SUMMARY.}

I. The structure of the stem and leaf of Podocarpus spinulosus is similar to that of other species described respectively by Penhallow and Worsdell.

2. The structure of the microsporangium is similar to that of Saxegothaea and Araucaria, but the line of dehiscence is oblique.

3. Several prothallial cells are present in the pollen-grains of $P$. spinttlosus, as in other species of the Podocarpeae investigated. The walls of the prothallial cells break down at a later stage and their nuclei come to be free in the cytoplasm.

4. The generative cell of the pollen-grain sometimes divides in the same way as that described by Jeffrey and Chrysler as occurring in $P$. ferrugineus and $P$. dacrydioides.

5. The course of the vascular bundles in the female fructification is described in detail. One bundle from the peduncle passes into the megasporophyll, while a pair of bundles, one on each side of the sporophyll trace, unite and serve the ovule. The bundle thus formed has its xylem and phloem inversely orientated as compared with the megasporophyll 
bundle. At the chalazal end of the ovule it divides to form ultimately about four bundles which soon die out.

6. Podocarpus is regarded as a modified genus derived from a type similar to Saxegothaea.

7. The Podocarpeae are a natural group with no very definite connexions with the Taxeae, though Phyllocladus may form a connecting link. There is no evident relationship between the Podocarpeae and the Abietineae. It is likely that the former are connected with the Araucarieae by means of Saxegothaea.

Botany School, Cambridge, October, 1809 .

POSTSCRIPT.-Since this paper was sent in for publication we have received Tison's second paper on Saxegothaea (26). This author considers the epimatium and ovular stalk in Podocarpus as together equivalent to the epimatium in Saxegothaea. He also refers to two figures of the ovule of Saxegothaea published by one of us (17), which both show an epimatium 'qui enveloppe complètement l'ovule et son tégument à la façon de celui des Dacrydium et des Podocarpus.' One of these figures was a diagram to show the ovular supply arising as a branch from the sporophyll bundle and was not intended to show details of ovular structure. Nevertheless, inasmuch as it represented the epimatium as present on the under side of the ovule, it was incorrect. The other figure showed a section of the ovule cut more or less parallel to the cone scale, and so showed the epimatium present on both sides; it did not show an epimatium completely surrounding the ovule. Moreover, only on Tison's view can it be considered as proved that the epimatium completely surrounds the ovule in Podocarpus.

\section{LITERATURE.}

1. Bernard, C. : Le Bois centripète dans les feuilles des Conifères. Beihefte zum Botanischen Centralblatt, xvii, p. 293, 1904.

2. Bertrand, C. E. : Anatomie des Gnétacées et des Conifères. Ann. des Sci. Nat., Bot., sér. 5, $\mathrm{xx}, \mathrm{p} .5, \mathrm{I} 874$.

3. BEUST.: Untersuchungen über fossile Hölzer aus Grönland. Allgem. Schweiz. Gesellschaft, neue Denkschrift, xxix, I884,

4. Burlingame, L. L.: The Staminate Cone and Male Gametophyte of Podocarpus. Bot. Gaz., xlvi, p. 16I, I908.

5. Coker, W. C.: Notes on the Gametophytes and Embryo of Podocarpus. Bot. Gaz., xxxiii, p. 89,1902 .

6. Eichler, A. W. : Excursus morphologicus de formatione florum Gymnospermarum. Ann. des Sci. Nat., Bot., sér. 4 , xix, p. $257,1863$.

7. Favre, E. : Recherches sur la fleur femelle du Podocarpus sinensis. Ann. des Sci. Nat., Bot., sér. 5 , iii, p. 379,1865 .

8. Gothan, W.: Zur Anatomie lebender und fossiler Gymnospermen-Hölzer. Berlin, 1905.

9. Jeffrey, E. C., and Chrysler, M. A.: The Microgametophyte of the Podocarpineae. Amer. Nat., xli, p. 355 , I90\%. 
10. NoRÉN, C. O.: Zur Kenntnis der Entwicklung von Saxegothaea conspicua, Lindl. Svensk Botanisk Tidskrift, ii, p. 101, 1908.

11. Oliver, F. W.: The Ovules of the Older Gymnosperms. Ann. Bot., xvii, p. 45I, J903.

12. Penhallow, D. P.: The Anatomy of the Coniferales. Amer. Nat, xxxviii, 1904.

13. Pilger, R. : In A. Engler, Das Pflanzenreich, iv, 5. Taxaceae, p. 54, 1903.

14. Robertson, A. : Some Points in the Morphology of Phyllocladus alpinis, Hook. Ann. Bot., $\mathrm{xx}$, p. $259,1906$.

15. - The Taxoideae: a Phylogenetic Study. New Phytologist, vi, p. 92, 1907.

16. Seward, A. C. and Ford, Miss S. O.: The Araucarieae, Recent and Extinct. Phil. Trans. Roy. Soc., ser. B, cxcviii, p. $305,1906$.

17. Stiles, W.: The Anatomy of Saxegothaea conspicua, Lindl. New Phytologist, vii, p. 209, IgOS.

18. Strasburger, E. : Die Coniferen und die Gnetaceen. Jena, 1872.

19. $:$ Die Angiospermen und die Gymnospermen. Jena, 1879.

20. Thibout, E.: Recherches sur l'appareil mâle des Gymnospermes. Lille, I896.

21. Thomson, R. B. : Preliminary note on the Araucarieae. Science, N.S., xxii, p. 88, 1905.

22. - The Araucarieae-a Protosiphonogamic Method of Fertilization. Science,

23. N.S., xxv, p. $27 \mathrm{I}, 19 \circ 7$.

24. - The Megasporophyll of Saxegothaea and Microcachrys. Bot. Gaz., xlvii, p. 345,1909 .

25. Tison, A. : La nucelle stigmatifère et la pollinisation chez le Saxe-Gothaea conspicua. Comptes Rendus, cxlvii, p. I37, 1908.

26. - : Sur le Saxe-Gothaea conspicua, Lindl. Mém. de la Soc. Linn. de Normandie, xxiii, p. 139,1909 .

27. Van Tieghem, P.: Anatomie comparée de la fleur femelle et du fruit des Cycadées, des Conifères et des Gnétacées. Ann. des Sci. Nat., sér. 5, x, p. 269, I869.

28. Veitch : Manual of the Coniferae. Edited by A. Kent, London, I900.

29. Worsdell, W. C.: On Transfusion Tissue. Trans. Linn. Soc., ser. 2, v, p. 30r, 1897 .

30. - Observations on the Vascular System of the Female Flowers of Coniferae. Ann. Bot., xviii, p. 527, 1899.

31. Young, Miss M. S.: The Male Gametophyte of Dacrydium. Bot. Gaz., xliv, p. I89, 1907 .

\section{EXPLANATION OF PLATE XXI.}

\section{Illustrating Messrs. Brooks and Stiles's Paper on Podocarpus.}

All the figures are of Podocarpus spinulosus.

Fig. I. Microsporophyll as seen in radial section through the cone. $\times 63$.

Fig. 2. Microsporophyll showing oblique dehiscence of sporangia. $\times 63$.

Figs. 3-8. Sections of pollen-grains showing contents. Stained with Heidenhain's Iron Alum Haematoxylin and Orange G. $\times 7^{2} 5$.

Fig. 9. Diagram of female fructification indicating the position of the sections shown in the following diagrams. levels.

Figs. 10-18. Diagrams representing sections through the female fructification at different

Fig. 19. Transverse section of the vascular bundle of a sterile scale of the female fructification showing two small isolated groups of xylem outside the main bundles. $\times 300$.

Fig. 20. Transverse section of, presumably, an integumentary vascular bundle showing a tendency to amphivasal structure. $\times 300$. 
Annats of Botany,

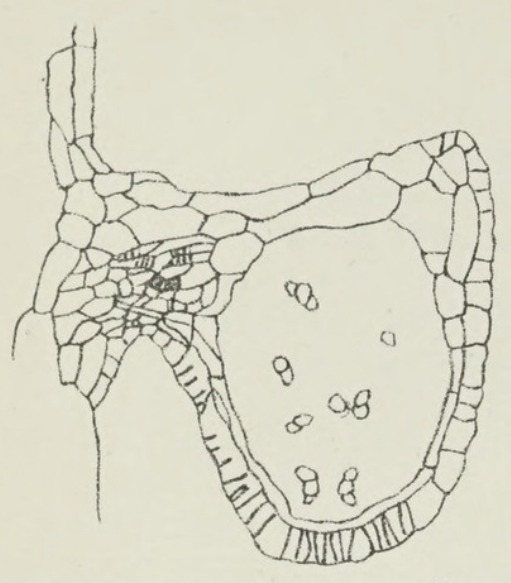

1.

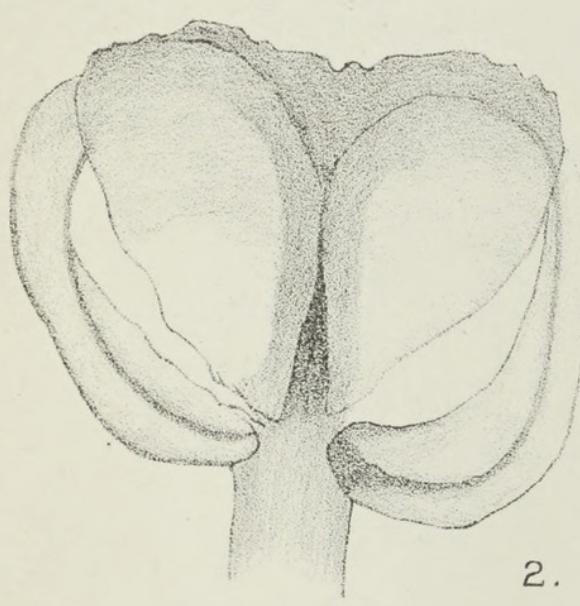

.

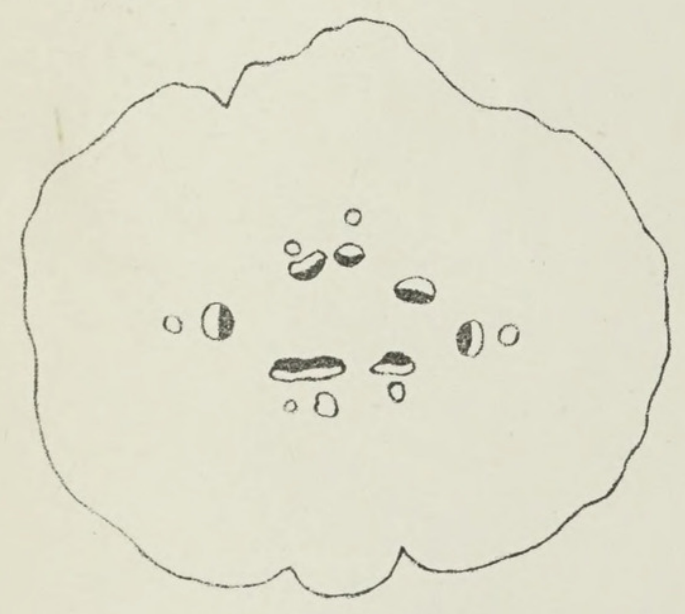

11.
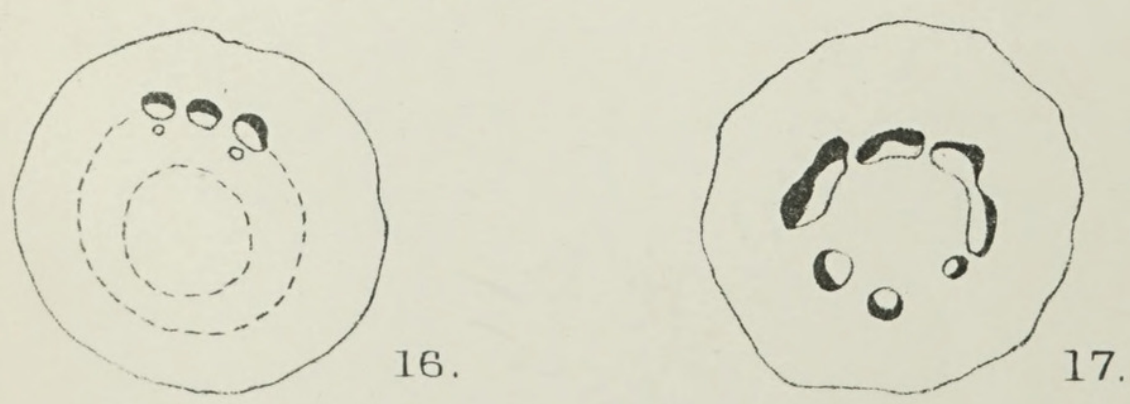

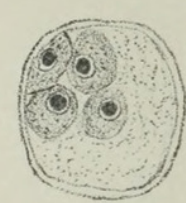

7.

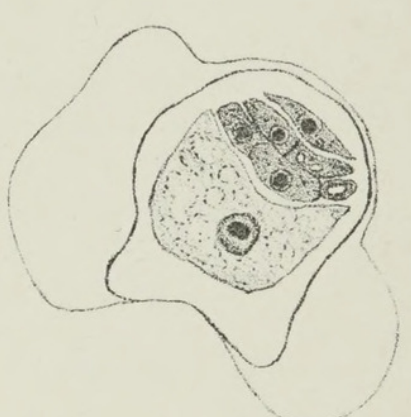

5.

6.

F. T.B. end W.S. del. BROOKS \& STILES - PODOCARPUS SPINULOSUS. 
Vol.XXIV.PL.XXI.

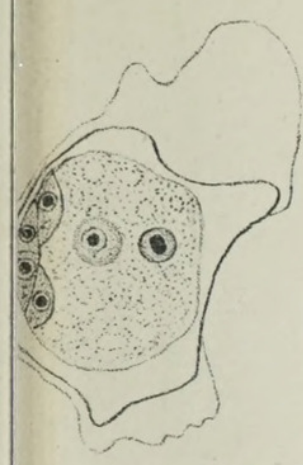

4.

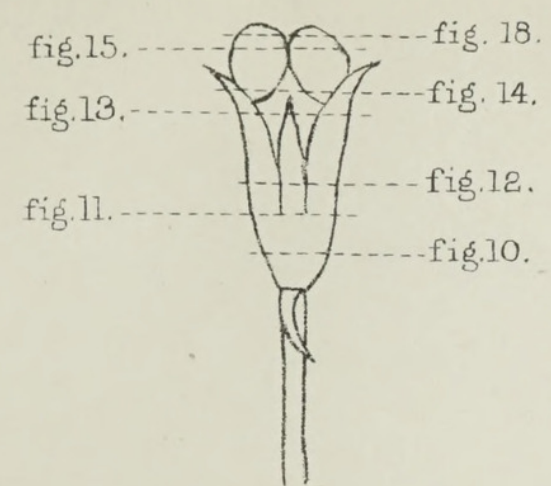

9

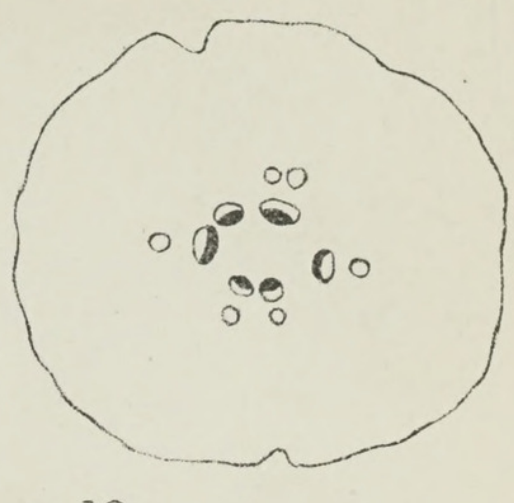

10.
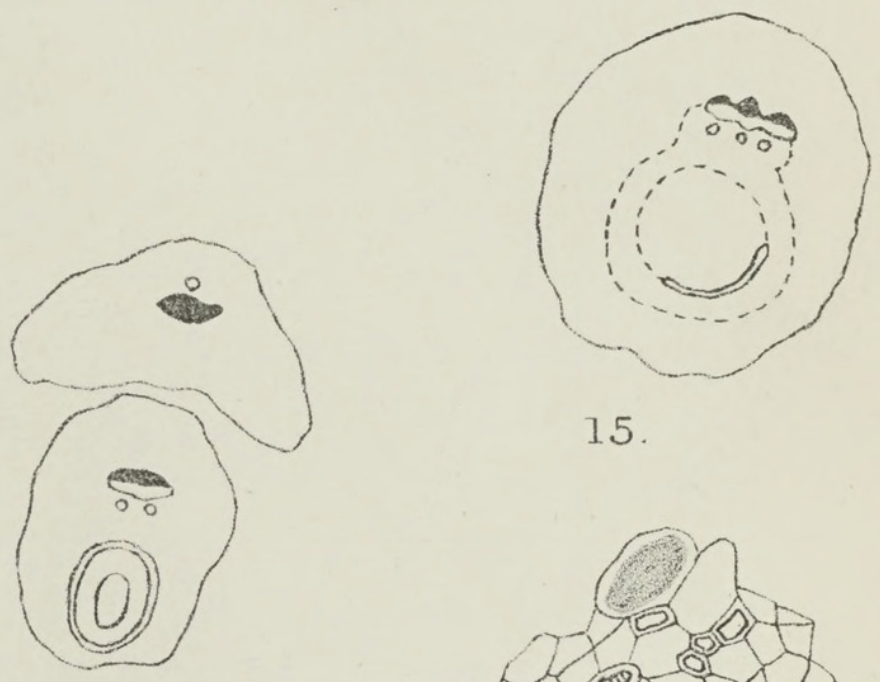

15.

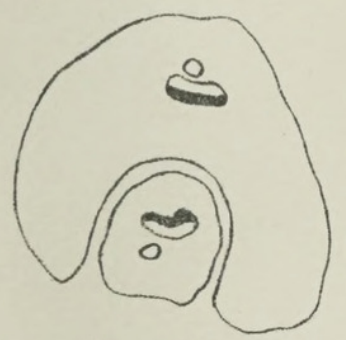

14.

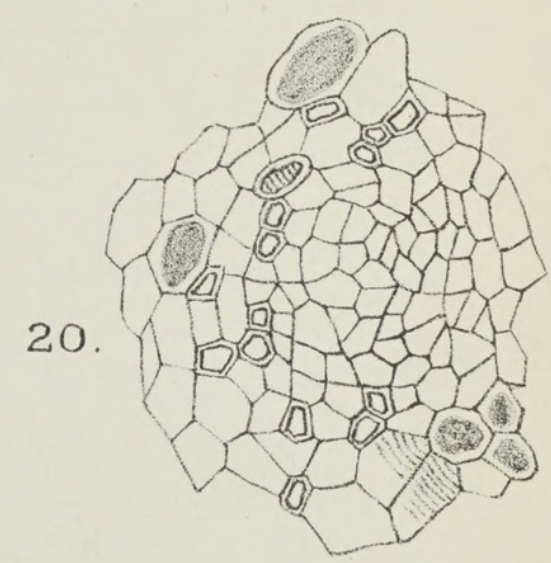

18.

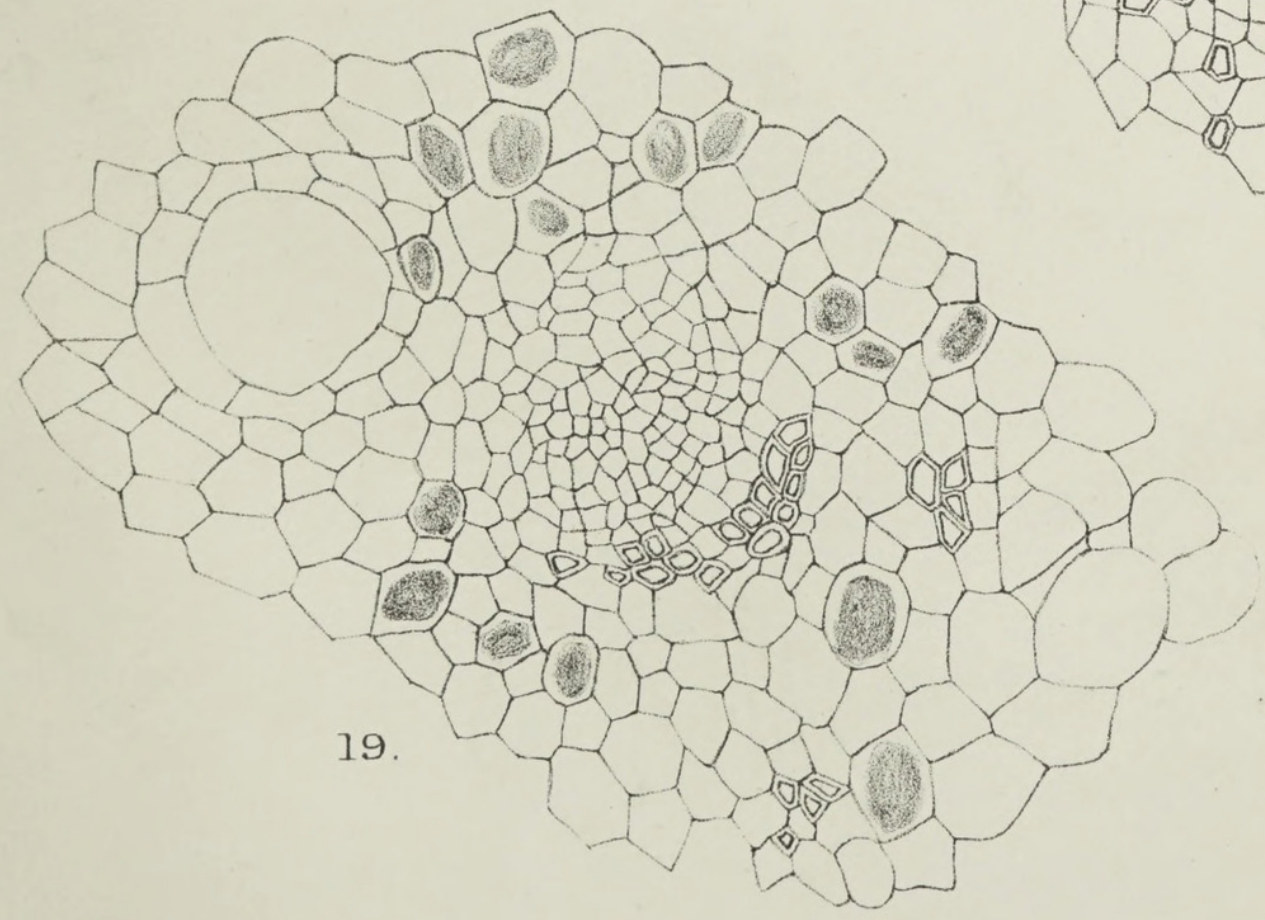




\section{$2 \mathrm{BHL}$ Biodiversity Heritage Library}

Brooks, F. T. and Stiles, Walter. 1910. "The structure of Podocarpus spinulosus, (Smith) R. Br." Annals of botany 24, 305-318. https://doi.org/10.1093/oxfordjournals.aob.a089268.

View This Item Online: https://www.biodiversitylibrary.org/item/262605

DOI: https://doi.org/10.1093/oxfordjournals.aob.a089268

Permalink: https://www.biodiversitylibrary.org/partpdf/319776

\section{Holding Institution}

New York Botanical Garden, LuEsther T. Mertz Library

\section{Sponsored by}

BHL-SIL-FEDLINK

\section{Copyright \& Reuse}

Copyright Status: Public domain. The BHL considers that this work is no longer under copyright protection.

This document was created from content at the Biodiversity Heritage Library, the world's largest open access digital library for biodiversity literature and archives. Visit BHL at https://www.biodiversitylibrary.org. 